\title{
The impact of fund attributes on performance: Empirical evidence for Polish equity funds ${ }^{* 1}$
}

\author{
Dariusz Filip ${ }^{2}$
}

\begin{abstract}
This article investigates the relationship between the attributes and performance of mutual funds in Poland. The study employs classic measures of return and the most popular organizational factors discussed in the financial literature. By using a relatively large dataset of 152 equity funds operating during the 2002-2015 period, we were able to find performance dependence on fund characteristics in samples consisting of domestic or foreign entities. The results obtained by means of panel data estimation indicate that fund size and expense ratio have a positive impact on the achieved returns. Fund age is treated as a parameter that influences performance in a negative way.
\end{abstract}

Key words: mutual funds, performance, CEE markets, fund attributes, fund characteristics

JEL classification: $G 11, G 23, G 29$

\section{Introduction}

The growth of mutual fund industry in Poland is an incontestable fact. This claim may be confirmed using various ratios - including the number of funds and the value of assets under management - that provide context for the evaluation of the dynamics of the increase in the financial sector over the last twenty years. However, the market is still defined as a developing one, where there is an effort to beat the market to confirm a deviation from the Efficient Market Hypothesis (cf. Dragotă,

\footnotetext{
Received: 27-08-2018; accepted: 27-11-2018

1 This work contains original new results based on the empirical study. The research project was supported by the National Science Centre, Poland (Narodowe Centrum Nauki) under Grant DEC-2014/15/D/HS4/01227.

2 Assistant Professor, Cardinal Stefan Wyszynski University in Warsaw (UKSW), Faculty of History and Social Sciences, Department of Finance. Wóycickiego St. 1/3, bl. 23, 01-938 Warsaw, Poland. Scientific affiliation: finance. Phone: +482256968 20.E-mail:d.filip@uksw.edu.pl.
} 
Tatu-Cornea and Tulbure, 2016; Ong and Sy, 2004). Consequently, there is a high demand for various rankings, analyses and reports concerning the functioning of collective investment institutions.

The clients' interests in the financial intermediaries from the countries of the Central and Eastern Europe Region (CEE) depend on a current market situation. This situation, in turn, determines the effects of asset management, regardless of the manager's ability in market forecasting. The financial literature on the subject largely concerns performance evaluation and only recently has begun assessing performance persistence (e.g., Filip, 2013; Urbański, 2017). The studies from developed markets also seek to find other ways of explaining better or worse returns, e.g., by analyzing the relationship between fund characteristics and performance.

The findings from international studies gave rise to analyzing fund attributes in emerging markets. This way of explaining the returns of collective investment institutions operating in the countries of the CEE Region opens a completely new chapter in the theory of finance. It should be mentioned that the issue of fund attributes has scarcely been studied in the CEE countries. Accordingly, this paper can be treated as an initial attempt to fill the existing research gap, with the exception of studies related to mutual fund effectiveness (e.g., Lemeshko and Rejnuš, 2015, Swinkels and Rzezniczak, 2009). Moreover, the use of a relatively large number of explanatory variables related to fund characteristics makes the study original and serves as a contribution to the existing literature.

The primary goal of the study was to examine if the performance of mutual funds operating in Poland is related to fund attributes. In this respect, it seems relevant to present the differences in how organizational aspects affect performance of individual groups of funds under the chosen segment or of funds with a particular geographical profile. Nevertheless, we have to stress that the performance depends on the movement of the index of stocks representing the universe of firms in which the fund can invest. All fund characteristics are only additional factors that can be considered by investors. The hypotheses serve to meet the objective formulated above and they are expressed as follows:

H1: The characteristics of mutual funds and collective investment companies do not influence fund performance.

$\mathrm{H} 2$ : The influence of fund attributes on performance is similar across individual groups of funds and across groups of funds with a particular geographical profile.

H3: The empirical results of performance determinants are unrelated to the measures of returns used.

Taking the above into account, it can be assumed that the empirical investigations concerning the relation between fund characteristics and the achieved returns are 
Dariusz Filip • The impact of fund attributes on performance: Empirical evidence...

important to the managers of collective investment companies as well as individual investors and, above all, to the theory of finance for a number of reasons. First, the mutual fund participants may take fund attributes into account when making their investment decisions. Second, mutual funds can use favorable classification resulting from the characteristics implied by their informational and marketing actions. Third, from the cognitive perspective, the studies enhance the knowledge about the similarities and differences between financial intermediaries in the developed and developing countries.

The remainder of this paper proceeds as follows. Section 2 is a brief overview of the financial literature related to the attributes-performance relationship. Section 3, the methodology, presents the applied empirical strategy. Section 4 documents the description of dataset and results achieved from the conducted analysis. Section 5, the discussion part, explains obtained findings. The paper ends with a conclusion.

\section{Literature review}

Fund attributes are defined as characteristics that determine the management profile of fund companies and help funds gain advantage on the market. The organizational aspects of mutual funds' functioning may also be treated as a determinant of performance. The issue of charging management expenses, which limit the raw returns, and the issue of non-organizational aspects (e.g., turnover ratio and risk) related to investment style have been addressed in early performance analyses.

As one of the pioneers in mutual fund research, Sharpe (1966) examined the performance of open-end mutual funds operating during the 1954-1963 period. Despite the lack of statistical significance, the results showed that the returns achieved by funds included in the sample were below the benchmark. He also noticed that the difference in fund performance was essentially due to the variation in expense ratio. Studies undertaken in the late 1980s reinvigorated the discussion. For example, Ippolito (1989), who analyzed performance of U.S. funds, determined that for the entities operating during the 1965-1984 period, the risk-adjusted returns (net return, accounting for fees and expenses) were similar to the returns achieved by index funds.

The factor of risk, which results from the variability of returns achieved by the entities, is not directly linked to organizational aspects of funds' functioning. There are numerous studies on this issue (e.g., Detzel and Weigand, 1998; Bliss, Potter and Schwarz, 2006); however, these studies do not always reveal the significance of the determinant of performance. A recent study worth considering due to the use of interesting research methods and the specificity of the analyzed market is one by Vijayakumar, Sivanmalaiappan and Chandrasekhara Rao (2012), who examined the relation between performance and fund characteristics in India. The study sample 
consists of 14 funds that invested in equity and debt-linked assets during the 20042008 period. By means of panel methods, i.e., ordinary least squares (OLS), fixedeffect estimation (FEM) and random-effect estimation (REM), the authors revealed that the effects of asset management are positively related with nonsystematic risk.

At the turn of the century, there was a shift in scholarly discussion towards the factors related to fund characteristics resulting from their functioning on the market. Fund size, as one of the fund attributes, began to be considered in performance analyses. It is assumed that the first paper on the issue was the study by Perold and Salomon (1991), who suggested that the increase in fund assets is followed by growth in the number of transactions. This is due to the requirement of building a diversified portfolio, which, in turn, increases the fund transaction costs that are reflected in higher fees charged to clients. This phenomenon, combined with lower portfolio liquidity, came to be known as diseconomies of scale.

As of today, the works by Indro et al. (1999) and Chen et al. (2004) are considered classic scholarly papers on the subject. According to the first, focusing on a large sample of non-indexed U.S. equity funds and mixed funds operating during the 1993-1995 period, fund assets may influence performance. Indro et al. (1999), using risk-adjusted and fee-adjusted returns, reported that funds have to maintain the minimal size of assets to achieve sufficient performance allowing them to cover trading costs by charging fees. By means of return regression they also showed that after overrunning the optimal level of assets under management, the returns were negative.

The second of the abovementioned studies investigates the economies of scale in the functioning of mutual funds by using a specific methodological approach proposed by Fama and MacBeth. On the basis of a sample of 741 equity funds operating during the 1962-1999 period and by means of returns from one, three and four-factor CAPM model, Chen et al. (2004) were able to find negative and statistically significant impact of fund size on performance, the so-called erosion effect.

Another area of investigation related to fund characteristics focuses on fund age. Most relevant studies reported statistically insignificant results, e.g., papers by Golec (1996) or Lee, Yen and Chen (2008) that analyzed the U.S. market (the most developed market) and Taiwanese market (an emerging market) respectively. However, there are papers presenting empirical results that can be assessed as well. For instance, Payne, Prather and Bertin (1999) used data on growth, aggressive growth, growth and income, equity income and balanced funds. The relation between fund attributes and performance was analyzed with a pooled OLS regression, and the results indicated a slight but positive impact of fund age on performance. Yap and Pierce (2008) conducted a cross-sectional study, in which they employed a time-series regression method for random effects, between 
estimations and the Fama-MacBeth estimations. Having measured the effects of assets management of 168 Australian open-end equity funds from the 2002-2006 period by means of Jensen's alpha, conditional Jensen's alpha and augmented Carhart model including illiquidity premium, they found that funds with higher management fees and longer period of existence underperform.

One of the rarely examined fund-describing factors is related to the size of the asset management company to which a given fund belongs. The previously referenced paper by Chen, Hong, Huang and Kubik (2004) provided statistically significant arguments supporting the claim that funds that belong to larger asset management companies obtain comparatively higher investment results than their competitors from smaller fund families. Other interesting findings came from the study by $\mathrm{Fu}$ and Liu (2015), who used data concerning, among other components, fund size and fund family size, while analyzing the study sample composed of 188 Taiwanese equity funds (excluding foreign and regional funds). By means of regression models for panel data, they noticed that medium funds from larger asset management companies obtain higher performance as measured by raw return as well as fourfactor return.

Most of the abovementioned studies concern the U.S. market. However, an increasing number of researchers focus on explaining fund performance in countries with emerging markets. The analyses concerning the mutual fund industry in Central and Eastern European countries, including Poland, are scarce. Bóta and Ormos (2016) analyze the returns and risk factors in mutual funds from the CEE region. In an attempt to find a local advantage for them, the researchers point to substantial differences in the investment results generated by European and non-European funds. Determinants of Polish fund performance, in turn, are discussed by Białkowski and Otten (2011) and by Filip (2017). Both the studies use regression models. The first study examines the influence of expense ratio, fund age and fund assets, whereas the second looks only at fund assets in relation to the doubtful erosion effect. The obtained results confirmed marginal but positive impact of asset management values on performance. However, due to the limitations of these two studies, there is a justified need for an analysis of performance determinants of mutual funds in Poland that would focus on a relatively long time horizon and use several other research approaches. Moreover, further studies in the area contribute to the existing finance literature and broaden the discussion about fund attributes by presenting new evidence from developing countries (e.g., Mamatzakis and $\mathrm{Xu}, 2016$; Tang, Wang and $\mathrm{Xu}, 2012$ ). In addition, the scarcity of empirical research in this area in the CEE countries results mainly from the absence of relevant databases containing information about the attributes characterizing particular funds. Thus, findings from developing markets may show some differences from and similarities to those from more developed markets, as described in the existing literature. 


\section{Methodology}

From the earlier literature, it is apparent that the fund that has a specific character outperformed the other funds with similar objectives. Hence, the main objective of the study is to examine if returns are related to fund characteristics, the possession of which may result in improved performance. Moreover, we will verify the main thesis, according to which there are statistically significant relations between performance and fund attributes. The identification of these attributes is crucial since mutual funds in developing countries play an increasing role in the functioning of the financial systems.

The different performance measures used in this study are explained in this section along with the research approach. The diversity of the methods used shall improve the credibility of research findings.

\subsection{Measurement of returns}

Since the results are sensitive to the applied measure of returns, it seems reasonable to use the most popular tools for evaluating the quality of asset management. We will therefore use a set of complementary measures for calculating risk-adjusted return based on monthly excess return. The first one is the original Sharpe measure (before its modification in 1994), called reward-to-variability ratio (Sharpe, 1966):

$$
\text { Sharpe }_{i, t}=\frac{\bar{r}_{i, t}-r_{f, t}}{\sigma\left(r_{i, t}\right)}
$$

where Sharpe $i, t$ is the Sharpe measure of fund $i$ in the period $t ; \bar{r}_{i, t}$ is the mean rate of return achieved over the period $t$ by fund $i ; r_{f, t}$ stands for the mean risk-free return over the analogous period; $\sigma\left(r_{i, t}\right)$ is the standard deviation of the rate of return on fund $i$ in the period $t$, and it represents total risk. The ratio describes the level of excess return that can be earned for the extra volatility associated with holding a riskier asset. The mean rate of return and standard deviation are calculated on the basis of monthly observations.

Another measure utilized in this study is a modified version of the previous one. The performance evaluation is conducted using a weighted average of deviation from expected return, which is lower than the mean value, the so-called semivariance or downside deviation. The Sortino measure allows for the calculation of downside variability, which takes account losses, but not unexpected gains, as expressed in the following formula (Sortino and Price, 1994):

$$
\text { Sortino }_{i, t}=\frac{\bar{r}_{i, t}-r_{f, t}}{\theta\left(r_{i, t}\right)}
$$


where Sortino $_{i, t}$ is the Sortino measure of fund $i$ in the period $t ; \theta\left(r_{i, t}\right)$ is the semideviation of negative returns of fund $i$ in the period $t$, and it represents downside risk. The deviations of negative returns are calculated based on monthly observations.

The following measure is similar to the preceding ones but includes systematic risk. The reward-to-volatility ratio, also known as Treynor measure, is calculated as follows (Treynor, 1965):

$$
\text { Treynor }_{i, t}=\frac{\bar{r}_{i, t}-r_{f, t}}{\beta\left(r_{i, t}\right)}
$$

where Treynor ${ }_{i, t}$ is Treynor measure of fund $i$ in the period $t$; and $\beta\left(r_{i, t}\right)$ stands for values of systematic risk of fund $i$ and estimated sensitivity of the fund return to the benchmark variations. The ratio allows evaluation of the potential returns in light of the underlying risk. Beta values are calculated based on monthly observations.

The last ratio used was the Carhart measure (1997). In this case, the risk-adjusted return was calculated as an intercept of the CAPM model, yet with four mimicking factors on the capital markets. The mentioned author expanded the Fama and French's three-factor procedure (1993) by the momentum effect according to the following formula:

$$
\begin{aligned}
& \operatorname{Carhart}_{i, t}=r_{i, t}-\left[\left(r_{f . t}+\beta_{i}\left(r_{m, t}-r_{f, t}\right)+\beta_{S M B}\left(S M B-r_{f, t}\right)\right.\right. \\
& \left.+\beta_{\text {HML }}\left(H M L-r_{f, t}\right)+\beta_{P R I Y R}\left(P R 1 Y R-r_{f, t}\right)\right]
\end{aligned}
$$

where Carhart $_{i, t}$ is the measure of abnormal return of fund $i$ in period $t ; r_{m, t}$ is the return on the local equity market benchmark in period $t ; r_{S M B}$ is the simple excess return on the $S M B$ portfolio, which means a difference in return between the small stock portfolio and the big stock portfolio; $r_{H M L}$ is the simple excess return on the $H M L$ portfolio interpreted as the difference in return between the high book-to-market portfolio and the low book-to-market portfolio in period $t ; r_{P R I Y R}$ is the simple excess return on the PRIYR portfolio, which means the difference in returns between a portfolio of past one-year winners and a portfolio of past one-year losers in period $t$; and $\beta_{S M B}, \beta_{H M L}$ and $\beta_{P R I Y R}$ are the measures of sensitivity of the fund return to changes in the $S M B, H M L$ and PRIYR factor returns, respectively.

The study adopted the annualized return of the stock market portfolio which was the main local market index (WIG) for domestic funds and global equity benchmark that represents stock performance across 23 developed markets (MSCI World) for foreign funds. The values of benchmark were gathered from the Warsaw Stock Exchange and Morgan Stanley Capital International websites. Moreover, the values of factor-mimicking portfolios ( $S M B, H M L$ and $P R I Y R)$ were obtained from 
the online data library of Adam Zaremba for domestic funds (http://adamzaremba. $\mathrm{pl} /$ downloadable-data/) and Kenneth R. French for foreign ones (http://mba.tuck. dartmouth.edu/pages/faculty/ken.french/index.html). A proxy for the riskless rate was the weighted average yield on 13-week T-bills sold at auctions. The data of risk-free rates came from International Financial Statistics quarterly reports conducted by the International Monetary Fund.

\subsection{Empirical approaches}

While verifying the formulated hypotheses, it is justified to use several methodological approaches to improve the statistical conclusion validity. Therefore, it is necessary to construct panel models using robust standard errors. The estimation of static panel models will be conducted through the application of the generalized least squares method (GLS) and least squares dummy variables (LSDV). The adopted approaches will be the random effects model (REM) and the fixed-effects model (FEM) respectively (cf. Bollen and Brand, 2010). The panel data regression model is represented in the following equation:

$$
\text { Perf }_{i, t}=f\left(\text { Size }_{i, t} ; \text { Age }_{i, t} \text { Expense }_{i, t} ; \text { Family }_{i, t} ; \text { Group }_{i}\right)
$$

where $\operatorname{Perf}_{i, t}$ is a model-specific measure of the return of fund $i$; Size indicates the fund size and is computed as a natural logarithm of the value of assets under management of fund $i$ in a given year; Age stands for the fund age and is calculated as a natural logarithm of the number of months from the first pricing of unit share; Expense indicates the expense ratio and is calculated as the sum of yearly operational costs of fund $i$ in relation to the possessed assets under management; Family is the size of the asset management company (fund family) to which fund $i$ belongs, and it is computed as a natural logarithm of the total assets of funds under asset management company in a given year; and Group indicates the dummy variables and takes the value 1 if a domestic fund invested in small- and medium-cap equities, 0 if a domestic fund invested in universal stocks. In relation to the second group of funds with a particular geographical profile, the value 1 means that a foreign fund invested in holdings from global developed markets, and 0 if a foreign fund invested in holdings from European emerging markets. In order to explain the effect of fund attributes on performance by taking the market situation into account, we decided to use the stock index return as a proxy (StockIndex).

Adding this variable enables a reference to the robustness of the obtained results to the turmoil occurring on the equity market in the analyzed period, i.e. the subprime mortgage crisis and the Eurozone crisis. The control variables in this case were the main Warsaw Stock Exchange index (WIG) for domestic funds and MSCI World for foreign funds. 
Including other variables in the model as control variables could contribute to robustness checks. The relevant literature mentions investment style, turnover ratio, liquidity ratio, management structure, or even minimal initial investment among such variables (cf. Haslem, 2017; Karagiannidis, 2010; Prather, Bertin and Henker, 2004). However, the limited availability of the data describing the operations of mutual funds in Poland resulted in the necessity to focus only on the basic fund attributes, as provided for in the finance literature.

\section{Empirical data and analysis}

The study sample consists of 152 open-end equity funds operating in Poland during the 2002-2015 period. The time horizon begins when the number of funds in the main groups of the segment of funds is adequately large for the purpose of conducting a thorough verification of the formulated hypotheses; it ends when the database for the present research project is completed. Table 1 presents the numbers of equity funds depending on the geographical location of their holdings in the period of the study.

Table 1: Number of mutual funds in chosen individual segments of funds

\begin{tabular}{|c|c|c|c|c|c|c|c|c|c|c|c|c|c|c|}
\hline Mutual funds & ণิ & ஜे & ষ্ণ & ஜे & ஜั & ঠి & $\stackrel{\infty}{\circ}$ & ஓे & $\stackrel{\circ}{\stackrel{1}{~}}$ & $\overline{\vec{~}}$ & $\stackrel{\sim}{\stackrel{1}{*}}$ & $\stackrel{m}{\stackrel{2}{\sim}}$ & 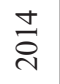 & $\frac{n}{i}$ \\
\hline Domestic, including: & 12 & 15 & 16 & 18 & 22 & 30 & 42 & 48 & 49 & 59 & 63 & 76 & 79 & 82 \\
\hline small and medium caps & 0 & 1 & 1 & 1 & 3 & 7 & 14 & 15 & 15 & 17 & 17 & 20 & 20 & 22 \\
\hline universal stocks & 12 & 14 & 15 & 17 & 19 & 23 & 28 & 31 & 32 & 38 & 42 & 50 & 53 & 53 \\
\hline Foreign, including: & 1 & 1 & 1 & 2 & 4 & 8 & 16 & 31 & 40 & 48 & 55 & 59 & 64 & 70 \\
\hline $\begin{array}{l}\text { global developed } \\
\text { markets }\end{array}$ & 0 & 0 & 0 & 0 & 0 & 0 & 1 & 2 & 4 & 5 & 6 & 7 & 8 & 11 \\
\hline $\begin{array}{l}\text { European emerging } \\
\text { markets }\end{array}$ & 0 & 0 & 0 & 0 & 2 & 6 & 6 & 12 & 12 & 14 & 15 & 16 & 17 & 19 \\
\hline Total & 13 & 16 & 17 & 20 & 26 & 38 & 58 & 79 & 89 & 107 & 118 & 135 & 143 & 152 \\
\hline
\end{tabular}

Source: Author's calculations

The sample size, presented in table 1, allows us to quantify the structure of the equity funds market. The domination of entities investing in domestic stocks is of no relevance since 2010. At the end of the time horizon, the number of domestic funds (82 entities) was slightly higher than the number of mutual funds investing in foreign securities (70 entities). The above table also presents the largest groups of domestic funds (invested in small and medium capitalization equity or universal stocks) as well as foreign ones (invested in holdings from global developed markets and European emerging markets) with a particular investment policy. 
The gathered data concerns monthly unit prices of mutual funds as well as organizational aspects of entities functioning in the fund industry. These data allowed the calculation of the effects of asset management by means of various measures of yearly returns. A preliminary description of dependent variables is presented in table 2 .

Table 2: Descriptive statistics for measuring performance

\begin{tabular}{|l|c|c|c|c|c|c|}
\hline \multicolumn{7}{|c|}{ Panel A: Domestic funds } \\
\hline Measure of Return & Observations & Mean & Median & $\begin{array}{c}\text { Std. } \\
\text { Deviation }\end{array}$ & Minimum & Maximum \\
\hline Sharpe & 611 & -0.0080 & 0.0968 & 0.4367 & -1.5625 & 0.9713 \\
\hline Sortino & 611 & 0.0313 & 0.1782 & 0.7974 & -2.8700 & 4.4150 \\
\hline Treynor & 580 & 0.0339 & 0.0532 & 0.2933 & -0.7808 & 1.1840 \\
\hline Carhart & 611 & -0.0004 & -0.0009 & 0.0085 & -0.0542 & 0.0379 \\
\hline \multicolumn{7}{|c|}{ Panel B: Foreign funds } \\
\hline Measure of Return & Observations & Mean & Median & $\begin{array}{c}\text { Std. } \\
\text { Deviation }\end{array}$ & Minimum & Maximum \\
\hline Sharpe & 400 & 0.0116 & 0.0295 & 0.4042 & -1.1363 & 1.1641 \\
\hline Sortino & 396 & 0.0377 & 0.0427 & 0.8230 & -3.1070 & 4.0625 \\
\hline Treynor & 400 & 0.0012 & 0.0010 & 0.1284 & -1.5811 & 1.4846 \\
\hline Carhart & 400 & -0.0006 & 0.0017 & 0.0173 & -0.0651 & 0.0478 \\
\hline
\end{tabular}

Source: Author's calculations

As presented in table 2, the greatest variability was reported for Sortino measures and the lowest for Carhart's alphas in domestic as well as foreign samples. The mean yearly returns for the both samples of funds were positive for Sortino ratios and Treynor ratios. The measurement of returns by means of Carhart measures provided negative investment results. Sharpe ratios were positive for foreign funds and negative for domestic ones.

The characteristics and factors related to investment style, e.g., size, age, family size or expense ratio, served as a basis for examining the influence of fund attributes on performance. The yearly data for the explanatory variables was collected from Analizy Online, a Polish institution that publishes the fund information. The descriptive statistics related to independent variables are presented in table 3. 
Dariusz Filip • The impact of fund attributes on performance: Empirical evidence...

Table 3: Descriptive statistics for the fund characteristics

\begin{tabular}{|l|c|c|c|c|c|c|}
\hline \multicolumn{7}{|c|}{ Panel A: Domestic funds } \\
\hline Fund Characteristics & Observations & Mean & Median & $\begin{array}{c}\text { Std. } \\
\text { Deviation }\end{array}$ & Minimum & Maximum \\
\hline LN(Size) & 611 & 18.5309 & 18.6095 & 1.6237 & 13.4045 & 22.4123 \\
\hline LN(Age) & 611 & 4.1138 & 4.2047 & 0.7276 & 2.4849 & 5.4806 \\
\hline Expense & 609 & 0.0389 & 0.0401 & 0.0122 & 0.0030 & 0.1328 \\
\hline LN(Family) & 611 & 21.6599 & 21.6206 & 1.2319 & 17.5622 & 24.0802 \\
\hline \multicolumn{7}{|c|}{ Panel B: Foreign funds } \\
\hline Fund Characteristics & Observations & Mean & Median & $\begin{array}{c}\text { Std. } \\
\text { Deviation }\end{array}$ & Minimum & Maximum \\
\hline LN(Size) & 400 & 17.3297 & 17.2601 & 1.5404 & 12.9239 & 20.8887 \\
\hline LN(Age) & 400 & 3.7893 & 3.8918 & 0.6208 & 2.4849 & 5.2257 \\
\hline Expense & 400 & 0.0380 & 0.0396 & 0.0089 & 0.0000 & 0.0895 \\
\hline LN(Family) & 400 & 22.2541 & 22.6512 & 1.1279 & 18.2769 & 24.0802 \\
\hline
\end{tabular}

Source: Author's calculations

Given that the database contained the raw information about all entities, the performance of which was registered by the data provider, outliers needed to be excluded from the provisional data set. In the case of funds entering the market, the minimum value of the $A G E$ variable was 1 month, and the maximum value was 240 months. In both the cases, the limitations occurred only when collating the returns. The study took into account only the performance of funds from a maximum of 168 previous months (this is related to the starting date of the time horizon) and funds operating for more than 12 months. Relatively large deviations of values were observed for SIZE and FAMILY; the distribution of values is moderately or even highly positively skewed with a leptokurtic distribution, particularly in the case of the first variable. We decided to transform them into approximately normal data by using the natural logarithm. The applied procedure resulted in more symmetric distributions of the variables yet they were still not normally distributed. The factors of costs (EXPENSE) could be interpreted as predictor variables with moderate variability. Due to the specific nature of the variable, we did not interfere with the original data. In the next step, we shall analyze the correlations between the abovementioned variables.

The values of the correlation coefficients for the main variables are presented in table 4. A higher correlation coefficient was observed between the $A G E$ and SIZE factors (0.5044) as well as the FAMILY and SIZE factors (0.5579) in domestic funds. This result means that the older the analyzed fund or member of a large family fund, the larger the value of assets under its management. However, the levels of correlation have still let to include the mentioned variables in one model. In the remaining cases, the correlations were not meaningful. 
Table 4: Pairwise correlation coefficients of the independent variables

\begin{tabular}{|l|c|c|c|c|}
\hline \multicolumn{5}{|c|}{ Panel A: Domestic funds } \\
\hline & LN(Size) & LN(Age) & Expense & LN(Family) \\
\hline LN(Size) & 1 & 0.5044 & -0.3000 & 0.5579 \\
\hline LN(Age) & 0.5044 & 1 & -0.0993 & 0.3130 \\
\hline Expense & -0.3000 & -0.0993 & 1 & -0.3703 \\
\hline LN(Family) & 0.5579 & 0.3130 & -0.3703 & 1 \\
\hline \multicolumn{5}{|c|}{ Panel B: Foreign funds } \\
\hline LN(Size) & LN(Size) & LN(Age) & Expense & LN(Family) \\
\hline LN(Age) & 1 & 0.2850 & -0.0092 & 0.3549 \\
\hline Expense & 0.2870 & 1 & 0.0270 & 0.2420 \\
\hline LN(Family) & -0.0092 & 0.0270 & 1 & -0.2723 \\
\hline
\end{tabular}

Source: Author's calculations

The main findings presented below consist of two parts, wherein we discuss the results obtained for domestic (table 5) and foreign funds (table 6). The presentation of results occurs in several stages. First, the panels are defined as a different measure of returns. This step is followed by a collation of the values of regression coefficient for variables included in the individual models. All models are calculated by means of two methods of estimation: random-effects (REM) and fixed-effects (FEM). The values of test statistics describing a given model will follow each panel.

The first analyzed sample was a group of domestic funds, including ones investing in small and medium caps as well as universal stocks. Table 5 includes information about the values of regression coefficient for four models that treat the Sharpe, Sortino, Treynor and Carhart measures as dependent variables.

Due to a relatively large number of models included in table 5 in four panels, the interpretation of the obtained results will be done in two steps. Accordingly, it will be possible to provide a detailed description of test results and to present conclusions drawn from verifying the formulated hypotheses. A comparison of the estimation results for models presented in panel A, B and C reveals certain similarities. We detected a positive and statistically significant impact of expense ratio on performance measured by Sharpe, Sortino as well as Treynor ratios for domestic funds. The strong relationship is one between fund fees and investment results, i.e., the more expensive the fund, the higher returns it ensures to its clients. The SIZE and $A G E$ factors influenced returns of domestic funds in opposite manners. The former was positively and significantly related to risk-adjusted returns in all models where the mentioned measures were used. The latter had a 
negative impact on the Sortino ratio, the Treynor ratios and, in part, the Sharpe ratio. However, for some estimations, in particular where the market factor was used as a proxy, the influence of $A G E$ on fund performance was ambiguous. By introducing distinctions between funds in terms of investment policy, we obtained fragmented results, which may be related to the research method used. The FAMILY variables were statistically insignificant, in general.

The results could be the outcome of abnormal returns as a function of the dependent variables (e.g., Carhart measures). The EXPANSE and AGE variables influenced returns in different directions, i.e., the former had a positive impact on returns, whereas the latter influenced them negatively. However, this finding is relevant only when different methods of estimation are used. Nevertheless, the FEM's estimation seemed more adequate for the gathered data after running diagnostics using the Hausman (1978) statistic. The SIZE factor was insignificant when the Carhart measure was used as a dependent variable. Furthermore, the values of the Wald Chi-squared statistic indicate for the significance of all applied models. Moreover, it should be stressed that with a large number of observations for panel data and an endogenous variable with values in some interval, the low values of coefficients of determination are acceptable and should not serve to evaluate the quality of model fit (see Cox and Wermuth, 1992). On the other hand, including the stock index return as a proxy in the models results in much higher values of the $R$-squared and the adjusted $R$-squared. It means that, in the conducted regression analysis, a return on the local equity market benchmark should not be left out, especially when it explains the investigated relationship. Otherwise, the assumed specification of the model might be exposed to the omitted-variable bias.

As mentioned before, it is reasonable to analyze the fund attributes-performance relationship with respect to foreign funds separately. Fund characteristics can influence returns in different manners, depending on whether funds invest in global developed markets or European emerging markets. Table 6, similar to the previous table, includes the results of estimations in which Sharpe, Sortino, Treynor and Carhart measures served as dependent variables. 
Dariusz Filip • The impact of fund attributes on performance: Empirical evidence... Zb. rad. Ekon. fak. Rij. • $2018 \cdot$ vol. $36 \cdot$ no. $2 \cdot 465-488$

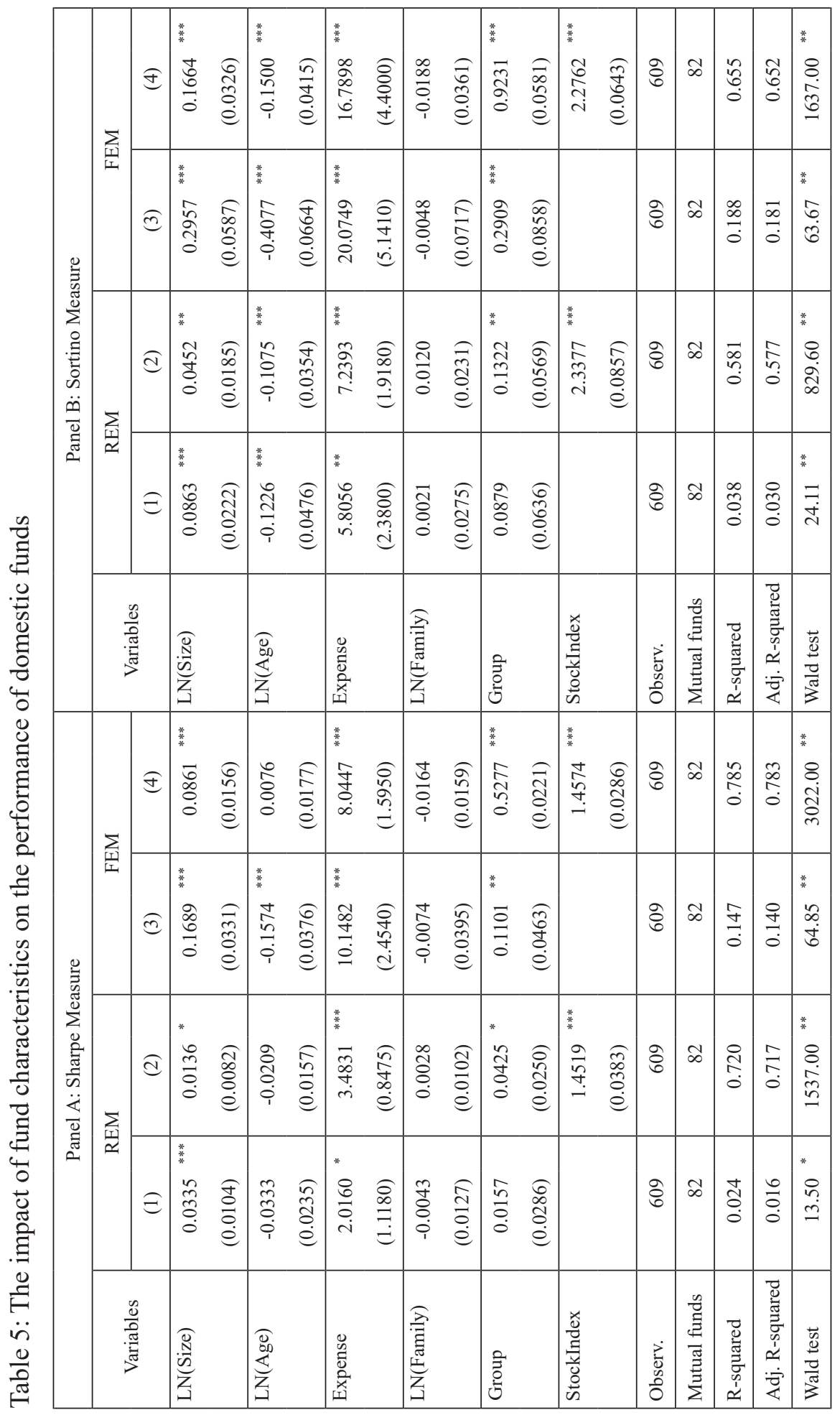


Dariusz Filip • The impact of fund attributes on performance: Empirical evidence...

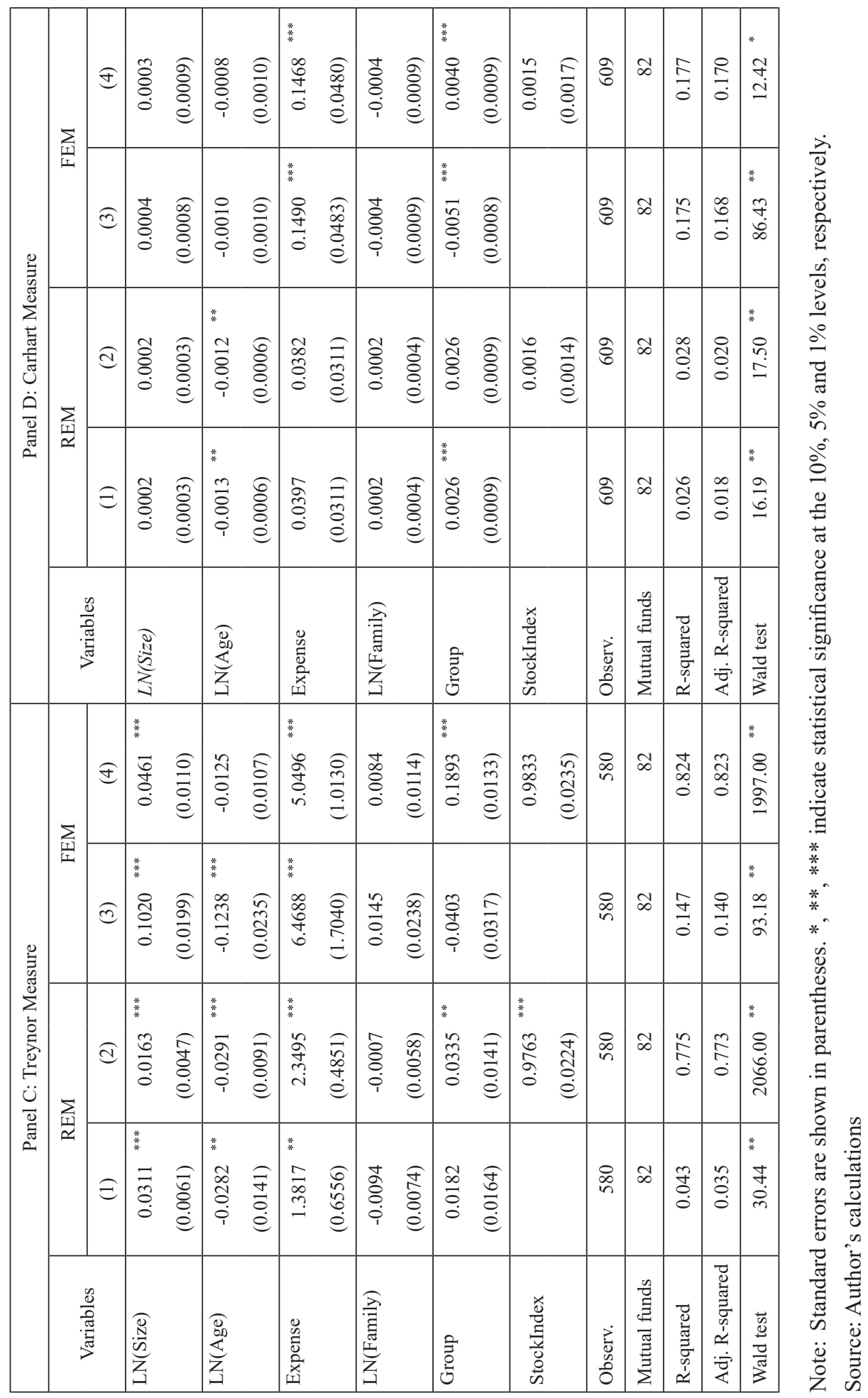


Dariusz Filip - The impact of fund attributes on performance: Empirical evidence... Zb. rad. Ekon. fak. Rij. • $2018 \cdot$ vol. $36 \cdot$ no. $2 \cdot 465-488$

\begin{tabular}{|c|c|c|c|c|c|c|c|c|c|c|c|c|c|c|c|c|c|c|}
\hline \multirow{5}{*}{ 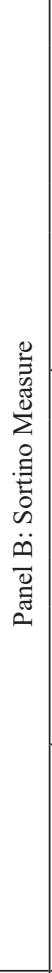 } & $\sum$ & త્ & 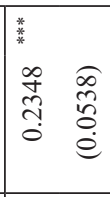 & 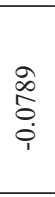 & $\begin{array}{l}6 \\
8 \\
0 \\
0\end{array}$ & $\begin{array}{l}\overrightarrow{\widehat{U}} \\
\infty \\
\infty\end{array}$ & $\begin{array}{l}\stackrel{尺}{8} \\
\infty \\
\stackrel{0}{0}\end{array}$ & $\begin{array}{l}{ }^{*} \\
g \\
\stackrel{0}{0} \\
\end{array}$ & $\begin{array}{l}\text { ô } \\
\text { ó } \\
\text { é }\end{array}$ & $\begin{array}{l}* \\
* \\
\infty \\
\infty \\
\infty \\
0 \\
1\end{array}$ & $\begin{array}{c}\widehat{\sigma} \\
\text { ले } \\
\stackrel{e}{e}\end{array}$ & $\begin{array}{l}* \\
* \\
* \\
0 \\
0 \\
\text { i }\end{array}$ & $\begin{array}{l}0 \\
\frac{0}{\infty} \\
\infty \\
0\end{array}$ & ڤे & $?$ & $\begin{array}{l}\hat{a} \\
\text { o. }\end{array}$ & 守. & 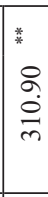 \\
\hline & $\frac{11}{I}$ & (્) & 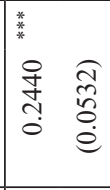 & & 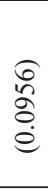 & $\begin{array}{c}\underset{b}{R} \\
\stackrel{i}{n}\end{array}$ & 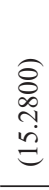 & $\begin{array}{l}\stackrel{\infty}{=} \\
\end{array}$ & 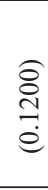 & $\begin{array}{l}\text { ?+⿱ } \\
\text { ñ. } \\
\text { in }\end{array}$ & $\begin{array}{l}\text { E } \\
\text { o } \\
\stackrel{+}{0}\end{array}$ & & & 임 & $?$ & $\begin{array}{l}\text { ָे } \\
\text { Oे }\end{array}$ & $\frac{m}{0}$ & $\begin{array}{l}* \\
* \\
\dot{m} \\
m\end{array}$ \\
\hline & $\sum_{i=1}$ & $\widehat{d}$ & 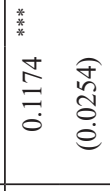 & 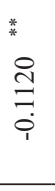 & $\begin{array}{l}6 \\
6 \\
0 \\
e\end{array}$ & $\begin{array}{l}\vec{F} \\
\text { bे } \\
\text { id }\end{array}$ & $\begin{array}{l}\stackrel{\mathbb{N}}{0} \\
\stackrel{0}{0} \\
\dot{J}\end{array}$ & $\begin{array}{l}n \\
m \\
0 \\
\stackrel{0}{0}\end{array}$ & $\begin{array}{l}\hat{\infty} \\
\hat{\tilde{O}} \\
\stackrel{e}{e}\end{array}$ & 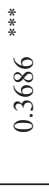 & $\begin{array}{l}\overparen{\Xi} \\
\Xi \\
\vec{e}\end{array}$ & 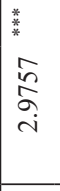 & $\begin{array}{l}\text { ปิ } \\
\stackrel{\Xi}{e} \\
\stackrel{e}{e}\end{array}$ & ஓे & $R$ & $\stackrel{m}{m}$ & 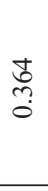 & 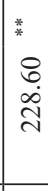 \\
\hline & $\vec{x}$ & 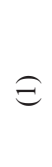 & $\begin{array}{ll}* & \\
* & \\
0 & 0 \\
\sim & 0 \\
\infty & \infty \\
0 & 0 \\
0 & 0 \\
0 & 0\end{array}$ & 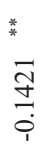 & $\begin{array}{l}\widehat{\hat{\Omega}} \\
\stackrel{\delta}{0} \\
\dot{e}\end{array}$ & $\begin{array}{l}\tilde{n} \\
\hat{n} \\
\end{array}$ & $\begin{array}{l}\widehat{\S} \\
\text { aे } \\
\text { +̇ }\end{array}$ & 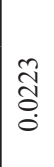 & $\begin{array}{l}\hat{\sigma} \\
\tilde{e} \\
\tilde{e} \\
\dot{e}\end{array}$ & ?. & 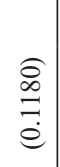 & & & §ి & $\stackrel{R}{1}$ & $\begin{array}{l}n \\
\tilde{o} \\
0\end{array}$ & $\begin{array}{l}\text { fo } \\
\text { Oे }\end{array}$ & $\stackrel{*}{*}$ \\
\hline & $\begin{array}{l}\frac{y}{2} \\
\frac{5}{5} \\
\frac{\pi}{5}\end{array}$ & : & $\begin{array}{l}3 \\
\vdots \\
\vdots \\
\vdots \\
\vdots\end{array}$ & 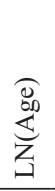 & & 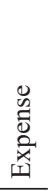 & & 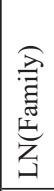 & & 今े & & 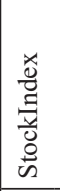 & & $\begin{array}{c}\dot{\vec{d}} \\
0 \\
0 \\
0 \\
0\end{array}$ & 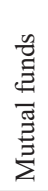 & 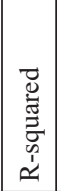 & 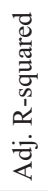 & 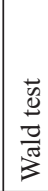 \\
\hline \multirow{5}{*}{ 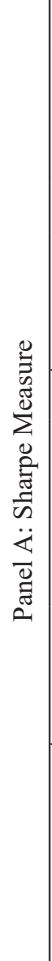 } & & త্త & 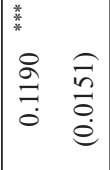 & 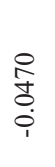 & $\begin{array}{l}\widetilde{q} \\
\stackrel{f}{\delta} \\
\stackrel{\leftrightarrow}{e}\end{array}$ & \begin{tabular}{l}
$*$ \\
\multirow{2}{*}{} \\
$\stackrel{+}{0}$ \\
$\infty$ \\
$\infty$
\end{tabular} & $\begin{array}{l}\stackrel{8}{8} \\
\stackrel{8}{+}\end{array}$ & $\begin{array}{l}\infty \\
0 \\
0 \\
0 \\
0 \\
1\end{array}$ & $\begin{array}{l}\widehat{\partial} \\
\text { ò } \\
\text { é }\end{array}$ & $\begin{array}{l}{ }^{*} \\
\underset{+}{\tilde{J}} \\
\stackrel{0}{1}\end{array}$ & $\begin{array}{l}\overparen{a} \\
\stackrel{0}{0} \\
\ddot{e}\end{array}$ & 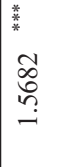 & $\begin{array}{l}\widehat{n} \\
\hat{\delta} \\
\stackrel{0}{0}\end{array}$ & \& & R & $\begin{array}{l}\text { to } \\
\stackrel{n}{0} \\
0\end{array}$ & $\begin{array}{l}\hat{n} \\
\text { nै }\end{array}$ & $\begin{array}{l}\text { * } \\
\text { * } \\
\stackrel{7}{7} \\
\stackrel{7}{7}\end{array}$ \\
\hline & 氢 & (2) & 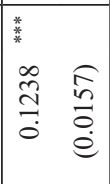 & 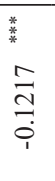 & $\begin{array}{l}0 \\
\infty \\
0 \\
0 \\
\dot{0}\end{array}$ & 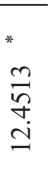 & 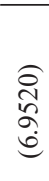 & $\begin{array}{l}\text { Oे } \\
\text { ठे. }\end{array}$ & $\begin{array}{l}\widehat{\hat{d}} \\
\stackrel{\delta}{e}\end{array}$ & $\begin{array}{l}0 \\
\check{0} \\
\vdots \\
0\end{array}$ & $\frac{\widehat{d}}{\stackrel{\widehat{a}}{e}}$ & & & \& & 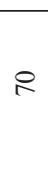 & त̊ & $\stackrel{0}{\stackrel{0}{0}}$ & * \\
\hline & \multirow{2}{*}{ 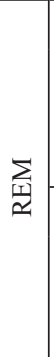 } & $\widehat{d}$ & 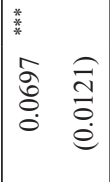 & 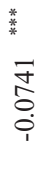 & 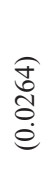 & $\begin{array}{l}\text { Oे } \\
\text { o. } \\
\text { - }\end{array}$ & 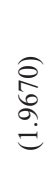 & $\begin{array}{l}\text { ठิ } \\
\text { ठ̊. } \\
\text { i. }\end{array}$ & $\begin{array}{l}\tilde{\delta} \\
\stackrel{0}{0} \\
\dot{e}\end{array}$ & 菜 & 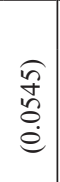 & 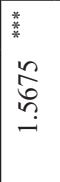 & 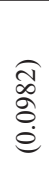 & \& & 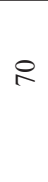 & 吕 & ભे & $\begin{array}{l}* \\
* \\
0 \\
0 \\
o \\
0 \\
0\end{array}$ \\
\hline & & 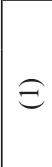 & 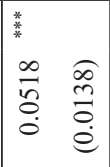 & 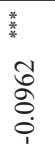 & $\begin{array}{l}\hat{\sigma} \\
\text { है } \\
\stackrel{0}{e}\end{array}$ & $\begin{array}{l}\stackrel{2}{2} \\
\text { ?े } \\
0\end{array}$ & 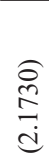 & $\begin{array}{l}\stackrel{2}{n} \\
0 \\
0\end{array}$ & $\begin{array}{l}\overparen{I} \\
\stackrel{\Xi}{a} \\
\stackrel{e}{e}\end{array}$ & 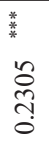 & $\begin{array}{l}\hat{\sigma} \\
\stackrel{0}{0} \\
e \\
e\end{array}$ & & & \& & 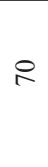 & $\begin{array}{l}8 \\
\stackrel{0}{0} \\
0\end{array}$ & 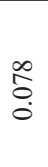 & $\stackrel{*}{*}$ \\
\hline & 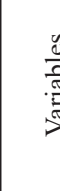 & 送 & 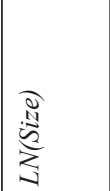 & 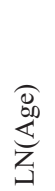 & & 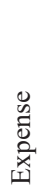 & & 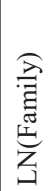 & & $\begin{array}{l}\text { जे } \\
\text { ثే }\end{array}$ & & $\begin{array}{l}\frac{x}{0} \\
\frac{0}{0} \\
\frac{0}{0} \\
\text { in }\end{array}$ & & 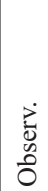 & 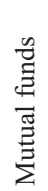 & 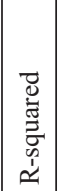 & 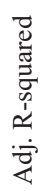 & $\begin{array}{l}\frac{4}{6} \\
\frac{0}{0} \\
\frac{\pi}{3}\end{array}$ \\
\hline
\end{tabular}


Dariusz Filip • The impact of fund attributes on performance: Empirical evidence...

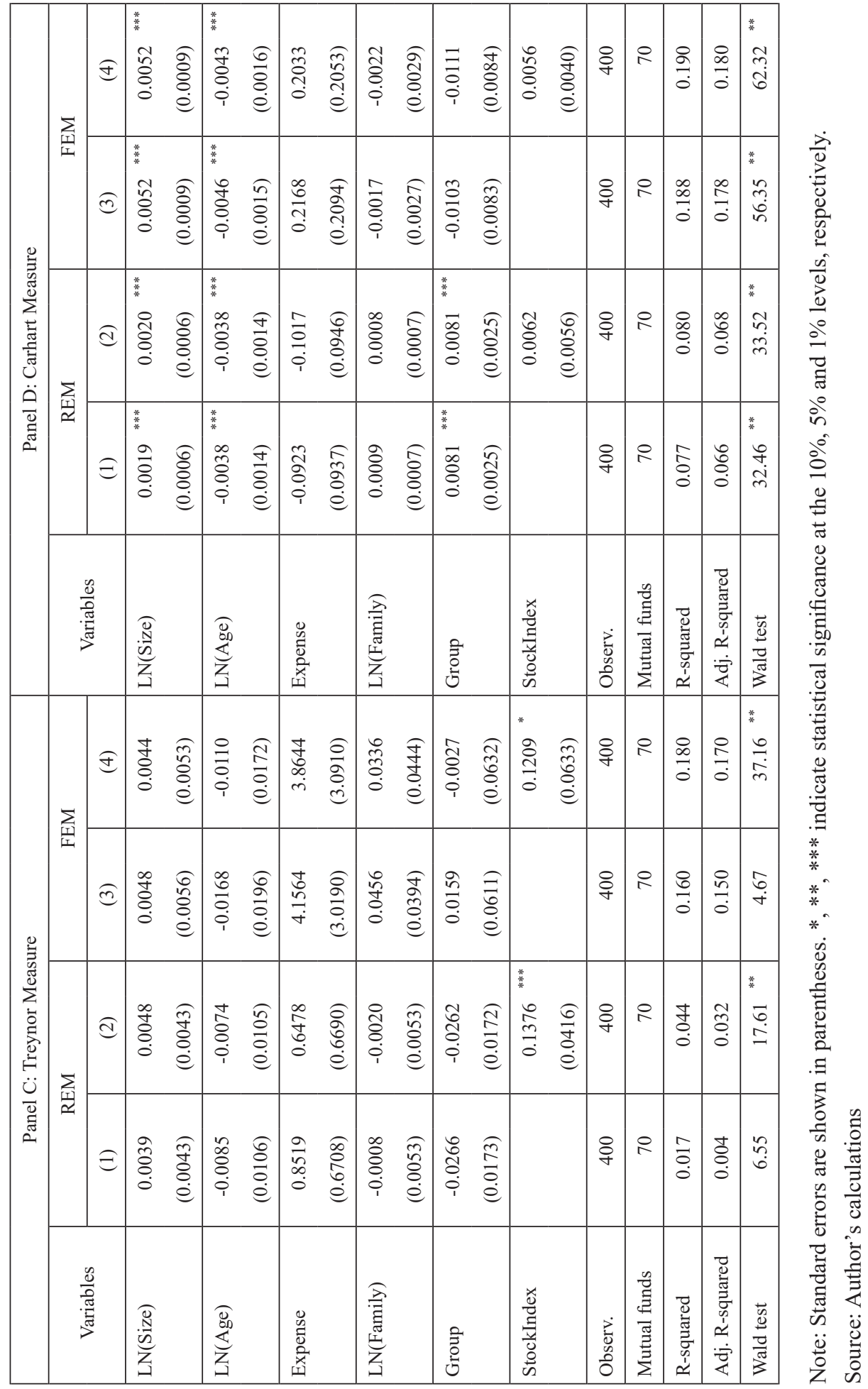


Due to the vast amount of findings presented in table 6 , there is a need for a separate analysis of fund attributes' influence on performance that would be conducted in relation to panel models used in the study and for the purpose of verifying the research hypotheses. The estimations for foreign funds provided results in strong support of the thesis that fund characteristics influence performance.

The SIZE factor concerning fund assets was of statistical significance in almost all models of panels, except for the Treynor ratios. Accordingly, foreign funds operated in Poland assets under management, next to market factors, can be treat as a determinant of performance. The expense ratio, as opposed to the results concerning domestic funds, were much less of a relevant factor in the results, and the interpretation thereof is unequivocal. The $A G E$ variables, which explained the included four measures of return, revealed a similar relationship. We noticed that fund age was found to be a parameter negatively influencing performance of foreign funds, which could be even more visible that in the case of domestic ones, in particular when Carhart measures served as endogenous variables. The same as in the case of results obtained using the domestic subsample, the control variables (GROUP) were substantially important but mostly with the REM's estimation. Investing fund assets mainly in global developed markets contributes to better returns in comparison to other investments by foreign equity funds. The results obtained for Treynor ratios may potentially distort the findings due to the benchmark selection problem during their calculation for different foreign funds.

According to the Hausman test, which was conducted before the presented analysis, the individual-specific effects are correlated with the independent variables and hence the fixed-effects method fits better to the model than the random effects estimator. Introducing the control variable, StockIndex, made the values of coefficients of determination increase, which means that the regression models fit better to the observations. Moreover, given the results presented in Table 6, the variable associated with the situation on the securities market proved to be the most influential regressor for the achieved rates of return, which seems perfectly understandable in the case of equity funds. Nevertheless, regardless of the market situation and research approaches employed, the discussed findings turned out to be, in general, robust and consistent.

\section{Results and discussion}

In general, the results indicated the existence of several statistically significant relations. It turns out that the fund that manages a greater capital base and therefore has a greater capability to invest may generate better returns for both domestic and foreign funds. The additional benefits might emerge from using greater research resources or from having a greater influence on financial markets. The results 
correspond well with the findings of fund size by Białkowski and Otten (2011) or Filip (2017), which confirm the economies of scale in the functioning of Polish financial intermediaries and the possibilities of further increases in the level of assets that will not influence performance negatively.

Fund age, however, may be interpreted as a performance factor, especially for foreign funds. According to several estimations, older funds generate worse returns. This outcome means that making formulaic investment decisions based on experience combined with the lack of flexibility does not provide expected performance. In the mentioned paper by Białkowski and Otten (2011) on Polish funds, the age factor influenced returns negatively, but the finding was statistically nonsignificant. The findings reported in the present financial literature are more convincing.

The variable related to expenses had a positive sign in the models, especially for domestic funds, where it was of statistical significance. This result implies that a higher expense ratio is equivalent to higher fund returns. Hence, the level of management fees is positively related to the effect of asset management. This conclusion seems to be interesting, as it contradicts the findings presented in papers concerning both developed (e.g., Prather, Bertin and Henker, 2004) and emerging economies (e.g., Babalos, Kostakis and Philippas, 2009). However, there are also studies that draw conclusions similar to the ones reached in the present paper (e.g., Droms and Walker, 1996). We can also note the alternative interpretation of the results, that the higher returns the fund generates, the higher fees it is able to charge, implying that performance and fees are jointly determined. Therefore, the issue of better-performing funds raising their expenses deserves a separate analysis.

However, there are slight differences in the obtained results for the models applying risk-adjusted returns, such as Sharpe, Sortino and Treynor, as well as measures of abnormal returns: alphas of Carhart. The investigation which used two approaches showed that the FEM is characterized by marginally higher efficacy in achieving statistical significance of estimated parameters.

Lastly, it should be noted that the mutual fund market is, in relative terms, a high rotation labor market for portfolio managers. The high frequency of job change (cf. Khorana, 2001; Clare et al., 2014), which arises from managers moving from fund to fund as an effect of them being offered better financial conditions e.g. by large funds or the employer resigning from their services as a consequence of unsatisfactory investment performance, could cause such results. Therefore, an analysis of the connection between fund attributes, in particular ones regarding the size of the assets held, and the characteristics of managers themselves, especially manager tenure (e.g., Filbeck and Tompkins, 2004), appears to be a curious research area in the future. Moreover, the presence of the persistence phenomenon was perceived in mutual fund performance in many studies (e.g., Vidal-García, 2016), which also suggests that it is the dynamic model that should be a regression 
approach employed in future studies. A procedure allowing for lagged rates of return as independent variables might lead to a partial explanation of the current investment results and testing the persistence of mutual fund performance (e.g., Kaur, 2018; Belgacem and Hellara, 2011).

\section{Conclusions}

The purpose of the paper was to examine if the performance of mutual funds operating in Poland is related to fund attributes. All fund characteristics are additional features that can be considered by investors just after market factors. Taking the abovementioned observations into consideration, it should be noted that hypothesis $\mathrm{Hl}$ regarding the lack of fund characteristics' influence on performance should be rejected. The obtained results confirm the existence of fund attributes, e.g., fund size or expense ratio, that have a positive impact on the effects of asset management by foreign or domestic funds, as well as characteristics (especially fund age) that influence performance negatively. The verification of hypothesis $H 2$ regarding the different influence of attributes in individual groups of funds resulted in several findings. The differences in impact on performance driven by investment policy of equity funds were ambiguous. For domestic funds, we noticed an important relationship, which we analyzed by means of the fixed-effects method. However, the results obtained using the second method (random-effects estimates) suggested that performance may depend on investment policy but rather for foreign funds.

As for the separation of domestic and foreign funds, it was reflected in results obtained using both the methods. The effects of assets management by entities with the local stocks were relatively less sensitive to the size and age factors and more sensitive to expense ratio than the entities with foreign stocks. Therefore, the influence of a given fund attribute on performance is related to a particular geographical profile of equity fund. The hypothesis $\mathrm{H3}$ about the lack of possible discrepancies in the results obtained using the selected methods of performance measurement was verified negatively. The measures of return applied in the study varied in terms of their sensitivity towards fund attributes and their influence on performance. Nevertheless, it is difficult to indicate unambiguously which measures are more sensitive and which are less sensitive to the strength of the relationship.

This paper makes several contributions to the finance literature. Most importantly, the obtained findings show some differences from and similarities to the existing results concerning more developed markets, which are described in the relevant literature. Moreover, the findings extend the literature on the fund attributesperformance relationship by documenting some of the organizational factors that influence returns of domestic and foreign funds in a slightly different way. Second, the paper might be perceived as an original one. To the best of our knowledge, there 
are only a few empirical studies examining this relationship in the CEE countries. Therefore, our work is an attempt to fill in the existing research gap. Last but not least, the findings of this study include practical implications for mutual fund companies as well as investors, as mentioned earlier.

\section{References}

Białkowski, J., Otten, R. (2011) "Emerging market mutual fund performance: Evidence for Poland", The North American Journal of Economics and Finance, Vol. 22, No. 2, pp. 118-130 doi: 10.1016/j.najef.2010.11.001.

Babalos, V., Kostakis, A., Philippas, N. (2009) "Managing mutual funds or managing expense ratios? Evidence from the Greek fund industry", Journal of Multinational Financial Management, Vol. 19, No. 4, pp. 256-272, doi: 10.1016/ j.mulfin.2009.01.001.

Belgacem, S.B., Hellara, S. (2011) "Predicting Tunisian mutual fund performance using dynamic panel data model", The Journal of Risk Finance, Vol. 12, No. 3, pp. 208-225, doi: 10.1108/15265941111136950.

Bliss, R., Potter, M., Schwarz, C. (2008) "Performance characteristics of individual vs. team managed mutual funds", Journal of Portfolio Management, Vol. 34, No. 3, pp. 110-119, doi: 10.3905/jpm.2008.706248.

Bollen, K.A., Brand, J.E. (2010) "A general panel model with random and fixed effects: A structural equations approach", Soc Forces, Vol. 89, No. 1, pp. 1-34, doi: 10.1353/sof.2010.0072.

Bóta, G., Ormos, M. (2016) "Is There a Local Advantage for Mutual Funds That Invest in Eastern Europe?", Eastern European Economics, Vol. 54, No. 1, pp. 23-48, doi: 10.1080/00128775.2015.1120161.

Carhart, M.M. (1997) "On persistence in mutual fund performance", The Journal of Finance, Vol. 52, No. 1, pp. 57-82, doi: 10.2307/2329556.

Chen, J., Hong, H., Huang, M., Kubik, J.D. (2004) "Does fund size erode performance? The role of liquidity and organization", The American Economic Review, Vol. 94, No. 5, pp. 1276-1302, doi: 10.1257/0002828043052277.

Cox, D.R., Wermuth, N. (1992) "A comment on the coefficient of determination for binary responses", The American Statistician, Vol. 46, No. 1, pp. 1-4, doi: $10.2307 / 2684400$.

Detzel, F.L., Weigand, R.A. (1998) "Explaining Persistence in Mutual Fund Performance", Financial Services Review, Vol. 7, No. 1, pp. 45-55, doi: 10.1016/ s1057-0810(99)80012-2.

Dragotă, I.M., Tatu-Cornea, D., Tulbure, N. (2016) "Determinants of Development of the Mutual Fund Industry: A Socio-Cultural Approach", Prague Economic Papers, Vol. 25, No. 4, pp. 476-493, doi: 10.18267/j.pep.572. 
Droms, W.G., Walker, D.A. (1996) "Mutual Fund Investment Performance", The Quarterly Review of Economics and Finance, Vol. 36, No. 3, pp. 347-363, doi: 10.1016/s1062-9769(96)90020-4.

Elton, E.J., Gruber, M.J. (2006) Modern Portfolio Theory and Investment Analysis, Wiley John, US.

Fama, E.F., French, K.R. (1993) "Common risk factors in the returns on stocks and bonds", Journal of Financial Economics, Vol. 33, No. 1, pp. 3-56, doi: 10.1016/ 0304-405x(93)90023-5.

Filbeck, G. Tompkins, D.L. (2004) "Management Tenure and Risk-Adjusted Performance of Mutual Funds", The Journal of Investing, Vol. 13, No. 2, pp. 72-80, 10.3905/joi.2004.412310.

Filip, D. (2013) "Returns and Persistence of Investment Fund Performance in the Czech Republic", Prague Economic Papers, Vol. 22, No. 3, pp. 324-342, doi: 10.18267/j.pep. 455 .

Filip, D. (2017) "Mutual Funds: Does the Performance Erosion Effect Exist? Evidence from the Czech Republic, Hungary and Poland", Finance a úverrCzech Journal of Economics and Finance, Vol. 67, No. 6, pp. 512-538.

Fu, Y-F., Liu, H-Ch. (2015) "Fund size effect from the viewpoint of fund families evidence from Taiwan", Investment Management and Financial Innovations, Vol. 12, No. 1, pp. 189-197.

Golec, J.H. (1996) "The effects of mutual fund managers' characteristics on their portfolio performance, risk and fees", Financial Services Review, Vol. 5, No. 2, pp. 133-147, doi: 10.1016/s1057-0810(96)90006-2.

Haslem, J.A. (2017) "Mutual Fund Portfolio Manager Structures: Attributes, Implications, and Performance", The Journal of Wealth Management, Vol. 19, No. 4, pp. 115-127, doi: 10.3905/jwm.2017.19.4.115.

Hausman, J.A. (1978) "Specification tests in econometrics", Econometrica, Vol. 46, No. 6, pp. 1251-1271, doi: 10.2307/1913827.

Indro, D.C., Jiang, Ch.X., Hu, M.Y., Lee, W.Y. (1999) "Mutual Fund Performance: Does Fund Size Matter?", Financial Analysts Journal, Vol. 55, No. 3, pp. 7487, doi: 10.2469/faj.v55.n3.2274.

Ippolito, R.A. (1989) "Efficiency With Costly Information: A Study of Mutual Fund Performance, 1965-1984", The Quarterly Journal of Economics, Vol. 104, No. 1, pp. 1-23, doi: 10.2307/2937832.

Jensen, M. (1968) "The Performance of Mutual Funds in the Period 1945-1964", Journal of Finance, Vol. 23, No. 2, pp. 389-416, doi: 10.2307/2325404.

Karagiannidis, I. (2010) "Management team structure and mutual fund performance", Journal of International Financial Markets, Institutions \& Money, Vol. 20, No. 2, pp. 197-211, doi: 10.1016/j.intfin.2009.10.003.

Kaur, I. (2018) "Effect of mutual funds characteristics on their performance and trading strategy: A dynamic panel approach", Cogent Economics \& Finance, Vol. 6, No. 1, pp. 1-17, doi: 10.1080/23322039.2018.1493019. 
Lee, J.S., Yen, P.H., Chen, Y.J. (2008) "Longer tenure, greater seniority, or both. Evidence form open-end equity mutual fund managers in Taiwan", Asian Academy of Management Journal of Accounting and Finance, Vol. 4, No. 2, pp. $1-20$.

Lemeshko, O., Rejnuš, O. (2015) "Performance evaluation of equity mutual funds in countries with emerging economies: Evidence from BRIC, CEE, sea and MENA regions", Procedia Economics and Finance, Vol. 30, pp. 476-486, doi: 10.1016/S2212-5671(15)01315-5.

Mamatzakis, E. Xu, B. (2016) Managerial attributes and equity mutual fund performance. Evidence from China. MPRA Paper No. 76139, doi: https://mpra. ub.uni-muenchen.de/76139/.

Ong, L.L., Sy, A. (2004) The Role of Mature Market Mutual Funds in Emerging Markets: Myth or Mayhem? International Monetary Fund, Working Paper No. WP/04/133, doi: 10.2139/ssrn.588244.

Payne, T.H., Prather, L., Bertin, W. (1999) "Value Creation and Determinants of Equity Fund Performance", Journal of Business Research, Vol. 45, No. 1, pp. 69-74, doi: 10.1016/s0148-2963(98)00059-9.

Perold, A., Salomon, R.S. (1991), "The Right Amount of Assets under Management", Financial Analysts Journal, Vol. 47, No. 3, pp. 31-39, doi: 10.2469/faj.v47.n3.31.

Prather, L., Bertin, W.J., Henker, T. (2004) "Mutual fund characteristics, managerial attributes, and fund performance", Review of Financial Economics, Vol. 13, No. 4, pp. 305-326, doi: https://doi.org/10.1016/j.rfe.2003.11.002.

Sharpe, W.F. (1966), "Mutual Funds Performance", Journal of Business, Vol. 39, No. 1, pp. 119-138, doi: 10.1086/294846.

Sortino, F.A., Price, L.N. (1994) "Performance measurement in a downside risk framework", Journal of Investing, Vol. 3, No. 3, pp. 59-65, doi: 10.3905/ joi.3.3.59.

Swinkels, L., Rzezniczak, P. (2009) "Performance evaluation of Polish mutual fund managers", International Journal of Emerging Markets, Vol. 4, No. 1, pp. 26 42, doi: 10.1108/17468800910931652.

Tang, K., Wang, W., Xu, R. (2012) "Size and performance of Chinese mutual funds: The role of economy of scale and liquidity", Pacific-Basin Finance Journal, Vol. 20, No. 2, pp. 228-246, 10.1016/j.pacfin.2011.09.002.

Treynor, J.L. (1965), "How to Rate Management of Investment Funds", Harvard Business Review, Vol. 43, No. 1, pp. 63-75.

Urbański, S. (2017) "Short-, Medium- and Long-run Performance Persistence of Investment Funds in Poland", Bank i Kredyt, Vol. 48, No. 4, 343-373.

Vidal-García, J. (2016) "The persistence of European mutual fund performance", Research in International Business and Finance, Vol. 28, No. 3, pp. 45-67, doi: 10.1016/j.ribaf.2012.09.004. 
Vijayakumar, N., Sivanmalaiappan, M., Chandrasekhara Rao, K. (2012) “The Relationship Between Fund Performance and Fund Characteristics: Evidence from India", The IUP Journal of Applied Finance, Vol. 18, No. 2, pp. 5-18.

Yap, Ch. J., Pierce, R.M. (2008) "Managed Equity Fund Attributes and Performance. Australian Evidence", Proceedings of the $16^{\text {th }}$ Annual Conference on Pacific Basin Finance Economics Accounting Management PBFEAM in Brisbane, 2-4 July 2008, Brisbane, Australia, doi: 10.2139/ssrn.1296987.

\title{
Utjecaj fondova na uspješnost poslovanja na empirijskom primjeru dioničkih fondova u Poljskoj ${ }^{1}$
}

\author{
Dariusz Filip ${ }^{2}$
}

\begin{abstract}
Sažetak
Ovaj članak istražuje odnos između značajki investicijskih fondova i njihove izvedbe u Poljskoj. Studija koristi klasične mjere prinosa $i$ najpopularnije organizacijske čimbenike o kojima se raspravlja u financijskoj literaturi. Koristeći relativno veliki skup podataka od 152 fonda koji su djelovali tijekom razdoblja od 2002. do 2015. godine, uspjeli smo u uzorcima koji čine domaći ili strani entiteti pronaći ovisnost izvedbe o karakteristikama fondova. Rezultati dobiveni pomoću procjene panel podataka pokazuju da omjer veličine fonda i rashoda ima pozitivan utjecaj na postignute prinose. Starost fonda se tretira kao parametar koji negativno utječe na izvedbu.
\end{abstract}

Ključne riječi: investicijski fondovi, izvedba, tržišta Srednje i Istočne Europe, atributi fonda, karakteristike fonda.

JEL klasifikacija: G11, G23, G29

${ }^{1}$ Ovaj rad sadrži izvorno nove rezultate temeljene na empirijskoj studiji. Istraživački projekt podržan je od strane Nacionalnog znanstvenog centra u Poljskoj (Narodowe Centrum Nauki) pod brojem DEC-2014/15/D/HS4/01227.

2 Docent, Cardinal Stefan Wyszynski University in Warsaw (UKSW), Fakultet povijesti $i$ društvenih znanosti, Katedra za financije. Wóycickiego St. 1/3, bl. 23, 01-938 Varšava, Poljska. Znanstveni interes: financije. Tel.: +482256968 20.E-mail:d.filip@uksw.edu.pl. 